\title{
The Impact Of Service Quality And Consumer Decision Factors On Brand Equity
}

Ladda Vatjanasaregagul, (E-mail: vatjanas@nova.edu), Sukhothai Thammathirat Open University, Thailand Hwei. Cheng Wang, (E-mail: hwei.wang@email.aamu.edu), Alabama A\&M University

\begin{abstract}
The purpose of this study is to examine the relationship between service quality, consumer decision factors and brand equity in hotel industry. The population of this research is 17 brand name "Five star" and "Four star" hotels in Thailand. There is a survey on service quality, consumer decision factors and brand equity responded to by guests of the hotels. The samples for the study were 370 guests of the hotels. Paired samples t-statistics test method was used to test the differences and similarities of the mean response between service quality expectations and customers' perceived service quality. The research used descriptive statistics, correlation analysis and ANOVA to test the hypotheses. The results indicate that there was no significant difference between the expectation and perception of service quality of Thai hotels on all five dimensions. The results also indicate that there is no relationship between service quality and brand equity. However, the results indicate that there is a relationship between quality perception and consumer decision factors. Furthermore, a relationship was found between quality perception and brand equity in the hotels. In addition, the research found there is a relationship between consumer decision factors and brand equity. Moreover, the research found there is a relationship between service quality, consumer decision factor and brand equity. The contribution is derived from the works of Keller (1993) and the study of Aaker (1991), Aaker \& Biel (1993), Howard (1994) and Berry (2000).
\end{abstract}

\section{INTRODUCTION}

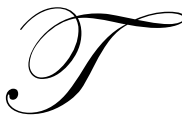

his research studies the relationship of service quality, consumer decision factors and brand equity. The results of this study should help marketers in making decisions on marketing activities for brand strategy to succeed and survive in a competitive environment. This research consists of Introduction, Review of Literature, Methodology, Analysis and Presentation of Findings, and Summary and Conclusions. It includes the background of the problem, purpose of the study, information on tourism and the hotel industry in Thailand, a statement of the problem, the research questions, assumptions and limitations, definitions of key terms, contributions of the dissertation, and a summary.

\section{LITERATURE REVIEW}

\section{Service Quality}

The definition of quality may vary from person to person and from situation to situation. The definitions of service quality vary only in wording but typically involve determining whether perceived service delivery meets, exceeds or fails to meet customer expectations (Cronin and Taylor, 1994; Oliver, 1993; Zeithaml, Berry and Parasuraman, 1993).

Parasuraman, Zeithaml and Berry (1988) define service quality as the degree and direction of discrepancy between the consumer's perceptions and expectations, or the extent to which a service meets or exceeds customer 
expectations. The quality of a service depends on that service consistently conforming to customers' expectations (Witt and Stewart, 1996).

Parasuraman, Zeithaml, and Berry $(1988,1990)$ projected a service quality model that identified perceived service quality into five dimensions: tangibility, reliability, responsiveness, assurance, and empathy.

1. Tangibles involve the appearance of physical facilities, including the equipment, personnel, and communication materials.

2. Reliablity involves the ability to perform the promised service dependably and accurately.

3. Responsiveness involves the willingness to help customers.

4. Assurance involves the knowledge and courtesy of employees and their ability to convey trust and confidence. This assurance includes competence, courtesy, credibility and security.

5. Empathy involves the provision of caring, individualized attention to customers. This empathy includes access, communication, and understanding the customer.

\section{Consumer Decision Factors}

Consumer decision factors are factors or variables of the consumer decision model. Every factor is the one that operates the consumer decision model as a system. Howard (1994) defines the consumer decision model as a model with six interrelated components or variables that are related to one another as shown in Figure 3 . The six factors of the model are information, brand recognition, attitude toward the brand, and confidence in judging the brand, intention, and purchase. The three central factors: brand recognition, attitude, and confidence make up the buyer's brand image.

\section{Brand Equity}

Brand equity is the positive marketing result from a certain good or service that has a brand name, such as high brand preference, market share or profit. Brand equity can be explained in two aspects: consumer's viewpoint and company's viewpoint. Consumers consider brand equity by comparing products with brands to products without brands. The products with brand names take advantage of customers more than the products without brand names. Companies believe that brand equity enhances products with brand names. Increased sales and profits are more associated with products with brand names as opposed to those without brand names. Brand equity has financial value in the long term as it influences profit for the company. Brand equity continually changes in the course of time like stock prices.

Several authors have studied brand equity:

Aaker defines brand equity as “.... a set of brand assets and liabilities linked to brand, its name and symbol, that add or subtract from the value provided by a product or service provided to a firm and/or to that firm's customer" (1991, p.15). For assets or liabilities to support brand equity, they must be linked to the name and /or symbol of the brand. If the brand's name or symbol should change, some or all of the assets or liabilities could be affected and even lost. However, some might be shifted to a new name and symbol.

Keller defines brand equity in terms of "the marketing effects uniquely attributable to the brand" (1993, p.1). Biel (1999) explains that brand equity can be thought of as the additional cash flow achieved by associating a brand with the underlying goods or services. Aaker (1996) also explains that the price premium should be the best measurement of brand equity and best indicate the strength of the brand. Beyond the physical assets related to the manufacture or provision of the product, brand equity involves the value of a brand as defined generally in economic or financial terms.

Biel (1999) states that brand equity is a result of the brand-building process. Brand image is broadly accepted as a key driver of equity. Brand equity is the additional discounted future cash flow achieved by associating a brand 
with an underlying product or service. The additional future cash flow at the end of the day is predicated on a buyer response to the branded offering which exceeds the response that same offering without brand identity would achieve.

\section{RESEARCH QUESTIONS AND HYPOTHESES}

Keller states, "Several research questions are relevant for managing customer-based brand equity" (1993, p. 17) in future research studies. This study utilizes the research questions developed by Keller (1993).

Research Question 1: Is there a significant difference between expectation and perception of each of dimension of service quality in brand name Thai hotels?

Hal: There is a difference between expectation and perception of each of dimensions of service quality in brand name Thai hotels.

Research Question 2: Is there a significant direct relationship between each dimension of quality perception and each of consumer decision factors?

Ha2: There is a positive relationship between each dimension of quality perception and each of consumer decision factors.

Research Question 3: Is there a significant direct relationship between each dimension of quality perception and brand equity?

Ha3: There is a positive direct relationship between each dimension of quality perception and brand equity.

Research Question 4: Is there a significant direct relationship between service quality and brand equity?

Ha4: There is a positive direct relationship between service quality and brand equity.

Research Question 5: Is there a significant direct relationship between each consumer decision factors and brand equity?

Ha5: There is a positive relationship between consumer decision factors and brand equity.

Research Question 6: Is there a significant relationship between service quality, consumer decision factors and brand equity?

Ha6: There is a relationship between service quality, consumer decision factors and brand equity.

\section{MEASUREMENT AND INSTRUMENT}

\section{Measurement}

Service quality will be measured according to how well perceptions of service quality match expectations of service quality. The multiple dimensions of service quality will be captured using the SERVQUAL instrument. Parasuraman, Zeithaml, and Berry $(1988,1990)$ identify the five dimensions of service quality which are tangibles, reliability, responsiveness, assurance and empathy. SERVQUAL will be used to assess customer expectations and perceptions based on the service quality gap model. Parasuraman and his colleagues $(1993,1994)$ concluded that the expectation section of the SERVQUAL survey instrument also questioned the perception section to capture the customer's opinions of expectation. Subtracting the expected items from the perceived items will produce a gap score.

Consumer decision factors - information, confidence, attitude, intention, and purchase - will be evaluated using and adapting the measurement scale that was developed by Howard (1994). Brand recognition will be measured 
by adapting the questionnaires that were developed by Darling and Wood (1990), Darling and Taylor (1993), Ettenson et al. (1988), and Johannson and Nebenzahl (1987).

Brand equity will be measured by adapting the questionnaires that were developed by Yoo (1996) and Yoo and Donthu (1997). Yoo (1996) developed a new brand equity scale, the Overall Brand Equity Scale, written specifically for his dissertation. It measures consumer-based overall brand equity and is based on a consumer survey developed separately from the measures of brand equity dimensions. Yoo and Donthu (1997) presented to the 1997 American Marketing Association's Summer Educators' Conference a technique to measure brand equity known as Yoo and Donthu's Brand Equity Scale. They used the brand equity concept of Aaker (1996) and Keller (1993) as the basis for the measurement.

\section{Instrument}

A questionnaire was developed and administered to a sample of customers' 17 five Stars and four star hotels in Thailand. The development of the instrument is based on a through literature review, and discussions with hotel industry personnel. The questionnaire, which was used in this study, describes the expectations and the perceptions of service quality, consumer decision factors and brand equity. The survey questionnaire includes five parts. Part I contains information involving classification variables. The classification variables are nationality, age, gender, marital status, income and how long the participants have stayed in the hotels. Part II and Part III contain 10 items, which represent 5 dimensions of service quality: tangibles (item 1 and 2), reliability (item 3 and 4), responsiveness (item 5 and 6), assurance (item 7 and 8) and empathy (item 9 and 10). Part II represents the expectation of service quality, but Part III represents the perception of service quality. Part IV contains 12 items, which represent the consumer decision factors: information (item 1 and 2), brand recognition (item 3 and 4), confidence (item 5 and 6), attitude (item 7 and 8), intention (item 9 and 10), and purchase (item 11 and 12). Part V contains 10 items, which represent the brand equity of the hotels. The data gathering instrument of the research will be 300 questionnaires for the sample of this dissertation.

\section{POPULATION AND STUDY SAMPLE SIZE}

The population of this research was the customers of 17 brand name "Five star" And "Four star" hotels in Thailand. Customers surveyed were guests of the hotel. The sample target for the study were 510 customers of the hotels. The customers may be Thai or other nationalities.

\section{DATA COLLECTION}

The researcher explained the purpose of the study and research process to the executives of the 17 five star and four star hotels whose customers were the population of this dissertation. The 510 questionnaires were distributed to customers of the 17 hotels, 30 questionnaires per hotel in April 2004. The respondents were informed that this survey was a part of Nova Southeastern University's doctoral dissertation requirement for the researcher.

The questionnaires were given to the hotel management who in turn asked guests in the lobby to complete the questionnaires. This was done while the guests were either checking out of the hotel, or relaxing in the lobby area. After completing the questionnaire, guests were asked to hand in at the reception desk. Complete confidentiality of responses was assured and maintained. The response rate was $72.50 \%$ or 370 completed questionnaires.

\section{DATA ANALYSIS}

The demographic classification of current study respondents analyzed frequency, percent, valid percent and cumulative percent. Expectation Scale, Perception Scale, Decision Scale and Brand Equity Scale compute Cronbach's Alpha for reliability Test. 
Paired samples t-statistics test method will be used to test the differences and similarities of the mean response between service quality expectations and customers' perceived service quality. The research used descriptive statistics, correlation analysis and ANOVA to test the hypotheses.

\section{OVERVIEW OF RESULTS}

The results of this dissertation show that service quality of Thai hotels (measured by) tangibles, reliability, responsiveness, assurance, empathy dimensions is perceived to be high by the guests. In addition, this study also finds there is a relationship between each dimension of quality perception: perception tangibles, perception reliability, perception responsiveness, perception assurance, perception empathy and each of consumer decision factors: information, brand recognition, confidence, attitude, and intension. Furthermore, this study also finds there is a relationship between each dimension of quality perception: perception tangibles, perception reliability, perception responsiveness, perception assurance, and perception empathy and brand equity.

According to test the model of this study, the results of this research finds there is no relationship between service quality and brand equity in the five star and four star Thai hotels. However, there is a relationship between consumer decision factors and brand equity in the five star and four star Thai hotels. Furthermore, this study finds there is a relationship between service quality, consumer decision factors and brand equity in the Thai hotel industry.

\section{MANAGERIAL IMPLICATIONS}

Based on the results from this research, several suggestions for hotel managers can be made. First, hotels should try to assess the expectations for service quality of their guests. This can be achieved by monitoring quality perception using the SERVQUAL dimensions of tangibles, reliability, responsiveness, assurance, and empathy by using consumer decision factors such as information, brand recognition, confidence, attitudes, and intentions. While better service quality does not necessarily encourage customers repeat usage of their brand choices, the accurate perception of service quality and little or no gap between service perceptions and expectations does. Therefore, the hotels should use measures of quality perception and customer decision factors to help increase brand equity.

Hotels and other service providers should integrate measures of service perceptions and expectations to generate information on the nature of the gaps, if any, between these two elements to develop training programs targeted at eliminating this gap. For example, guests may have expectations about the service provided, such as should the hotel have a restaurant, room service, parking, internet access in the rooms etc. At the same time marketing and advertising endeavors can build on the strengths of perceived quality to encourage customers. It is important to note that service quality and expectations are not static items. They will change over time so a continuous monitoring of these dimensions and appropriate managerial responses are critical to the long term health and success of the hotels.

The results of this study seem to validate the usefulness of the SERVQUAL model for use within the Thai hotel industry. Therefore, this approach is valuable in marketing and should also be considered as a useful tool in courses directed at providing information on how to improve service quality and the benefits from doing so. In a very competitive market, hotels need strategies to attract and keep customers. Hotels can achieve this by providing better guest services and a more consistent guest experience. In order to ensure that the match between perceptions and expectations is maintained hotels need remember not to neglect the basics. These include making sure the hotel is clean and comfortable and that everything is in working order. When something goes wrong during a stay, procedures must be in place to correct the problem quickly (i.e., implement appropriate service recovery strategies) and with minimal impact on the guest.

Quality management solutions provide the framework to manage guest experiences efficiently and costeffectively. Customers are requiring and demanding better services and the goals of all hotels must be to make the customers feel special. This will lead to customer's perceptions exceeding their expectations and greater customer satisfaction. A personal, proactive approach, such as knowing guest history, issues and preferences is vital to impressing customers and increasing repeat business. For example, the Ritz-Carlton Hotels excel in this area. Quality management has a role as well. The right quality management tools help staff to anticipate guest needs rather than 
react to them. For example, food preferences or known allergies can be respected, identified and compensated for. For those staying in the hotel on business, business support needs, like Internet access or overseas teleconferencing needs can be anticipated.

The people responsible for hotel marketing need to be aware that knowledgeable consumers demand value for their money. There is a need to uphold high levels of service and to maintain a progressive attitude. Upgrading levels of service, offering service guarantees, or the addition of new services can enhance guest stays. The hotel industry is moving toward higher standards of service. As a result, lower levels of service that previously allowed smaller properties to remain competitive are no longer acceptable. Hotel marketing staff must recognize the competitive trends in service and value addition as well as customers' increased awareness of the cost-benefit value of the product they are receiving. The study results demonstrate opportunities for marketing managers to expand their commitment to customer service. Management should research their customer base to generate valuable customer information and insights that can be used to create and tailor highly specialized services to meet the explicit needs of their customers.

\section{LIMITATIONS OF THE STUDY}

Every study tends to raise more questions than answers. This study focused on a limited number of hotels. The results indicate that the perceptions and expectations of service quality in hotels in Thailand were very similar. This has not been the case in related studies conducted in other countries and other service industries. The results are therefore limited in usefulness to these particular Thai hotels. It is unclear if similar results on issues like brand equity would be found if the gap between the perceptions and expectations of service quality were large. Further, it is unclear whether the small gap identified in this study is typical of most hotels in Thailand or a function of sampling.

This study only considered Thai hotels with similar ratings (Star count). There is evidence that different market segments generate different expectations and perceptions. For example, Mehta and Vera (1990) surveyed guests in a Singapore hotel, comparing their perceptions and contrasting these perceptions across a number of market segments. They found that key attributes used in selecting a hotel differed in each market segment. They concluded that it was critical for hotels to define precisely their target markets by purpose of travel. Since planning of services and facilities appear to be driven by key attributes for the segments that the hotel is serving, this is another limitation of the current study.

It should be noted that the conclusions are based on a relatively small sample of hotels. In addition, the research design in this study included only hotels but hotels are often only one component of a travel or vacation experience. Therefore, the generalizability of these results may not be appropriate for the travel or tourism industry as a whole. Extending these findings should be done only with careful consideration to the application of the appropriate variables like the service quality level of the hotel and the market the hotel wishes to serve (e.g., Tourists from Thailand or from overseas) In addition, the interaction of other factors, such as the time in the tourist season, how crowded the hotel is, relative room pricing or even the weather, in a total tourism experience of the perception of hotels was not considered here but may have an impact on the final outcomes. Finally, the direct link between the guests and the customer contact people was not specifically considered. This should also be taken into consideration in evaluating the results generated by this study since this interaction has been shown to be important to the total customer satisfaction experience.

\section{FUTURE DIRECTIONS FOR RESEARCH}

With the limitations discussed above in mind, it is worth suggesting some areas for potentially useful future research. First, more studies on service quality and brand equity should be undertaken to firmly establish if there is a consistent relationship between service quality and brand equity. If such a relationship exists it will provide good direction for marketing and related issues, like pricing and in-room services, for the hotel industry. It would be useful to use variables other than service quality and consumer decision factors, such as time of year or attending a scheduled conference, to see if they also play a role. 
This study looked at only one aspect of the tourism industry. It is reasonable to assume that hotels are just one part of a tourist total experience and that other experiences may play a role and impact the hotel service quality perceptions. For example, since Thai hotels cater to people from many different countries, cultural expectations may also play an important role in service quality issues for Thais and Thai tourists. Furthermore, researchers might investigate the possible impact that the number and availability of hotels in a country or the number of the rooms has on service quality. Lastly, future studies might consider the type of hotel, such as those with fewer stars than those included in this study or differences between locally owned hotels or those that are branches of international hotel chains. In addition, studies of the relationship, if any, between name awareness, brand loyalty, brand and other propriety assets and brand equity should be considered. Furthermore, the relationship between brand equity and financial performance in service brands has received little attention in the research literature and this is a relationship that should be more fully explored and understood.

\section{REFERENCES}

1. Aaker, D. (1991). Managing brand equity. New Year: The Free Press.

2. $\quad$ Aaker, D. (1996). Building strong brands. New York: The Free Press.

3. Aaker, D. \& Biel, A. (1993). Brand equity \& Advertising. USA: Lawrence Erlbaum Associates.

4. $\quad$ Beckford, J. (2002) Quality. New York: Routledge.

5. Berry, L. (2000). Cultivating service brand equity. Academy of Marketing Science, 28, 128-137.

6. Berry, L., Zeithaml, V., \& Parasuraman, A. (1985). Quality counts in services. Business Horizons, 28, 44-52.

7. Besterfield, D., Besterfield-Michna, C., Besterfield, G., \& Besterfield-Sacre, M. (2003). Total Quality Management. New Jersey: Prentice Hall.

8. Biel, A. (1999). Exploring brand magic. In J. Jones. (Ed.), How to use advertising to build strong brands. USA: SAGE Publications, Inc.

9. Brady, M. \& Cronin, J. (2001). Some new thoughts on conceptualizing perceived service quality: A hierarchical approach. Journal of Marketing, 65, 34-49.

10. Brady, M., Cronin, J., \& Brand, R. (2002). Performance-only measurement of service quality: A replication and extension. Journal of Business Research, 55, (1), 17.

11. Chaston, I. \& Mangles, T. (2002). Small business marketing management. Great Britain: Creative Print \& Design (Wales).

12. Cronin, J., \& Taylor, S. (1994). SERRVPERFF versus SERVQUAL: Reconciling performance-based and perceptions-minus-expectations measurements of service quality. Journal of Marketing, 58 (1), 125-131.

13. Darling, J. \& Taylor, R. (1993). An analysis of the competitive positioning abroad of U.S.versus U.S.S.R. as reflected by changes in the general attitudes of consumers. American Business Review, 11, 1-11.

14. Darling, J. \& Wood, V. (1990). A longitudinal study comparing perceptions of U.S.and Japanese consumer products in a third/ neutral country: Finland 1975 to 1985. Journal of International Business Studies, 21, 427450.

15. Davis, S. \& Dunn, M. (2002). Building the brand- driven business. San Francisco: John Wiley \& Sons, Inc.

16. Ettenson, R., Gaeth, G., \& Wagner, J. (1988). Evaluating the effect of country-of -origin and the Made in USA campaign: A conjoint approach. Journal of Retailing, 64, 85-100.

17. Heung, V., Wong, M., \& Qu, H. (2000). Airport-restaurant service quality in Hong Kong: An application of SERVQUAL. Cornell Hotel \& Restaurant administration Quarterly, 41 (3),_86.

18. Howard, J. (1994). Buyer behavior in marketing strategy. New Jersey: Prentice Hall.

19. Huber, J., Holbrook, B., \& Khan, B. (1986). Effects of competitive context of an additional information on price sensitivity. Journal of Marketing Research, 23, 230-260.

20. Johansson, J. \& Nebenzahl, I. (1987). Country- of- origin, social norms, and behavioral intentions. In S.T. Cavusgil (Ed.) Advances in International Marketing. Connecticut: Jai Press Inc.

21. Keller, K. (1993). Conceptualizing, measuring, and managing customer-based brand equity. Journal of Marketing, 57, 1-22.

22. Knowles, J. (2001). The role of brands in business. In Brand: Vision and values. New York: John Wiley \& Sons, Ltd.

23. Lambin, J. (2000). Market-driven management: Strategic and operational marketing. New York: St. Martin's Press. 
24. Marconi, J. (2000) The brand marketing book. USA: NTC Business Books.

25. Mariampolski, H. (2001) Qualitative market research. London: SAGE Publications Ltd.

26. Mouradian, G. (2002). The quality revolution. New York: University Press of American.

27. Oliver, R. (1993). A conceptual model of service quality and service satisfaction. Advances in Service Marketing and Management, 2, 65-85.

28. Parasuraman, A., Berry, L., \& Zeithaml, A. (1990). An Empirical Examination of Relationships in an Extended Service quality Model. Cambridge, MA: Marketing Science Institution.

$29 . \quad$ (1991). Refinement and reassessment of the SERVQUAL scale. Journal of Retailing, 67, 42-

50.

30. (1993).Research note: More on improving service quality measurement. Journal of Retailing. 69 (1), 140-147.

31. Parasuraman, A., Zeithaml, V., \& Berry, L. (1985). A conceptual model of service quality and its implications for future research. Journal of Marketing, 49, 41-50.

32. (1988). SERVQUAL: A multiple-item scale for measuring consumer perceptions of service quality._Journal of Retailing, 64 (1),_12-40.

33. (1994). Reassessment of expectations as a comparison standard in measuring service quality: Implications for further research._Journal of Marketing, 58 (1), 111-124.

34. Peter, J. \& Donnelly, J. (2000). A preface to marketing management. Boston: Irwin McGraw-Hill.

35. Pyo (2001) Benchmarks in hospitality and tourism. New York: The Haworth Hospitality Press.

36. Teas, K. \& Agarwal, S. (2000). The effects of extrinsic product cues on consumers' perceptions of quality, sacrifice, and value. Journal of the Academy of Marketing Science, 28, 2, 278-290.

37. Temporal, P. (2002). Advanced brand management. Singapore: John Wiley \& Sons (Asia) Pte Ltd.

38. Tollington, T. (2002). Brand assets. English: John Wiley \& Sons Ltd.

39. Tourism Authority of Thailand. (2003). Accomodations. Retrieved 2003, from http://www.tourismthailand.org/home.ph

40. Yoo, B. (1996). The effects of marketing efforts and culture con brand equity formation. Dissertation. College of business administration, Georgia State University.

41. Yoo, B. \& Donthui, N. (1997). Developing and validating a consumer-based overall brand equity scale for Americans and Koreans: An extension of Aaker's and Keller's conceptualizations. Presented at American Marketing Association's Summer Educators' Conference, Chicago, IL.

42. Zeithaml, V. (1987). Defining and relating price, perceived quality, and perceived value. Cambridge: Marketing Science Institution.

43. _ (1988). Consumer perceptions of price, quality, and value: A means-end model and synthesis of evidence. Journal of Marketing Research, 52, 2-22.

44. Zeithaml, V., Berry, L., \& Parasuraman, A. (1988). Communication and control processes in the delivery of service quality._Journal of Marketing, 52, 35-48.

45. Zeithaml, V., Berry, L., \& Parasuraman, A. (1993). The nature of determinants of customer expectations of services. Journal of Academy of Marketing Science, 21, Winter, 1-12. (1996). The behavioral consequences of service quality. Journal of Marketing. 60 (2), 31-46.

46. Zeithaml, V., Parasuraman, A., \& Berry, L. (1990). Delivering Quality Service Balancing Customer Perceptions and Expections. New York: The Free Press.

47. _ (1987). In S.T. Cavusgil (Ed.) Advances in international marketing._Greenwich, Connecticut: Jai Press Inc., 